\title{
The Independence of Public InQuiries: DIXON V. CANADA
}

\section{PeTER Desbarats ${ }^{*}$}

The decision of the Chretien government early in 1997 to prematurely terminate the Commission of Inquiry into the Deployment of Canadian Forces to Somalia immediately raised questions about the relationship between public inquiries and the governments that appoint them and, above all, the degree of independence that such inquiries require in order to function effectively. These questions already have been addressed in two judgments, first in the Trial Division of the Federal Court' and subsequently in the Federal Court of Appeal, ${ }^{2}$ but it is certain that neither is definitive. It is just as certain that the debate about the future of public inquiries will intensify in the future. Now that the government has raised the issue in such dramatic form, questions about the independence of public inquiries will be in the foreground from now on whenever governments resort to inquiries to deal with situations that overwhelm ordinary political processes.

While it is too soon to define the ultimate effect of the government's decision in the case of the Somalia inquiry, it might be useful to touch briefly on some of the issues that it has raised. This comment is offered merely to sketch out some of my own early reactions to the government's decision and the court judgments, as a non-lawyer intimately involved in the whole process.

As I have stated in the extracts from my personal journal published recently by McClelland and Stewart under the title Somalia Cover-Up: A Commissioner's Journal, ${ }^{3}$ I accepted the invitation to join the Somalia inquiry without giving much thought to the question of its independence. Neither did the two judges who were my fellow Commissioners, as far as I could tell at the time. It was not something that we discussed in the early stages. I assumed that our inquiry would have the same degree of independence as the hundreds of other federal inquiries that have been appointed since Confederation, as the many inquiries that I had covered as a journalist, as the Royal Commission on Newspapers of 1980-81 where I had served as associate research director and senior consultant, and as various other inquiries since then to which I had contributed research or advice related to my own field of journalism and communications. In none of these do I recall the question of independence from government as being a topic of discussion or concern.

Peter Desbarats was a Commissioner of the Commission of Inquiry into the Deployment of Canadian Forces to Somalia. He retired in 1996 as Dean of the Graduate School of Journalism at the University of Western Ontario, a position he assumed in 1981 after three decades in print and electronic joumalism. Létourneau Commission), [1997] F.C.J. No. 345 (T.D.) (QL) [hereinafter Dixon (T.D.)]. 1997). 
In what we already might refer to as the "good old days" of public inquiries in Canada when a long-established tradition of independent inquiries held sway, before the watershed events of our own case, it was simply assumed that governments would keep their hands off an inquiry once it had been set in motion. There was always widespread skepticism about the motives of various governments when they appointed inquiries, usually in an effort to damp down public controversy and get themselves off the hook for a time, but never about the ability of inquiries to accomplish what they had been asked to do. The fact that governments frequently turned to inquiries to remove controversies from the political agenda, at least for a time, testified to public confidence in the inquiry process. Canadians generally accepted inquiries as a straightforward, legitimate and non-political way to deal with such situations. This trust has been seriously damaged by the termination of the Somalia inquiry.

All three of us on the Somalia inquiry were novice commissioners. We soon discovered that the tricky question of political independence is effectively dealt with, on a day-to-day basis, through ongoing contacts between inquiry commissioners and staff and officials of the Privy Council Office. This is where crucial questions of time and money are negotiated - particularly money. It is through its control of inquiry spending that a government theoretically could exert some influence on the activities of an inquiry. In practice, this has not generally been done, at least not in critical areas of activity.

As Russell J. Anthony and Alastair R. Lucas state in A Handbook on the Conduct of Public Inquiries in Canada: "At all times the financing of the inquiry must be solely within the authority and discretion of the commissioners." 4

"The government's obligation is to appoint a trustworthy person as commissioner and, having done so, they must rely on the commissioner's good sense and judgment in determining what funds are required to carry out the commission's mandate," the Anthony-Lucas handbook went on to say. "To do otherwise would be to permit budgetary controls to fetter the inquiry's independence and affect its ability to fulfil its mandate."

Like most previous inquiries, our own soon settled into a routine of fairly constant negotiation and re-negotiation of deadlines and schedules with the Privy Council Office. It was soon evident to everyone that the original nine-month timetable was totally unrealistic. In the usual fashion, a series of extensions was granted. Despite impatient noises from Doug Young after he was appointed Defence Minister in late 1996, and a critical comment from the Prime Minister about our lack of deference toward senior military officers and civil servants who testified before us, none of us anticipated the abrupt order of 4 February 1997, giving us until 31 March 1997 to complete our hearings and until the end of the following June to submit our report. We had no suspicion that the government would break with tradition and in the process deliberately

(Toronto: Butterworths, 1985) at 42.

Ibid. 
open itself to accusations that it was participating in the cover-up of events following the murder of Shidane Arone, a Somali teenager, by Canadian soldiers in 1993.

The termination of a public inquiry for political reasons was so far outside the Canadian experience that we, as commissioners, were as astonished as the general public when it occurred.

Among those who were directly affected by this closure was John Dixon, a Vancouver academic and civil libertarian who had been a special advisor to Kim Campbell when she was Defence Minister during the time of Arone's murder. As a result of documents released by the Inquiry, Dixon was embroiled in a public dispute with officials at National Defence Headquarters over when Ms. Campbell and her staff had been informed of the Arone murder. At issue was the crucial principle of civilian control of the armed forces.

Dixon went to court in British Columbia when it became clear that the government's order to terminate the Inquiry would prevent him from testifying. On 1 April 1997, Judge Sandra J. Simpson of the Trial Division of the Federal Court agreed with Dixon's contention that the government had no right to terminate the Inquiry while leaving its terms of reference intact. ${ }^{6}$ Although it appealed Simpson J.'s ruling, the government also clarified the situation by issuing a new order requiring the Inquiry, in effect, to report on whatever parts of its terms of reference it had covered by the termination date.

This maintained the June 30 deadline and resolved the immediate uncertainty about the future of the Somalia inquiry, but it did nothing to resolve the issues raised by the February 4 Order-in-Council.

In dealing with these, Simpson J. prefaced her findings by dismissing the government's only professed reason for cutting short the Inquiry. We had not been, as the government maintained, extraordinarily slow or inefficient. On the contrary, according to Simpson J., we had worked "systematically and diligently" and "any suggestion that the Commission of Inquiry did not 'get on with it' would be wholly unwarranted."7 While Simpson J. of course did not speculate about the government's real motives, her rejection of the only explanation offered by the government was significant.

In its arguments before Simpson J., the government claimed that the Commission was not legally required to report on all items in its terms of reference. These were only "optional topics" for its final report. Simpson J. rejected this position, saying that the terms of reference or mandate of the Commission "did not give the Commissioners such a choice." 
"Where they are directed to inquire and report, the report must be meaningful," she wrote. "It cannot be a nil report or simply a list of unanswered questions as the Governor in Council has suggested." 9

Summing up one of the government's main positions, Simpson J. said that "the Governor in Council takes the view that it is entitled to treat the Commission of Inquiry like a government department which can be created, directed and disbanded as the Governor in Council sees fit."10

"There is no question that the Governor in Council can create a commission of inquiry, establish the mandate and appoint commissioners," Simpson J. wrote. "It can also set reasonable target dates and terminate a commission of inquiry in a lawful manner. However, in my view, a commission of inquiry is independent when its decisions relate to the manner in which it will carry out its mandate. I am also satisfied that this independence must mean that it is for the Commissioners, in a situation such as this where they are compelled to investigate and report, to decide when they had heard or otherwise received sufficient evidence to enable them to make findings of fact necessary to support conclusions in their report. In my view, the Governor in Council is not entitled to decide when the Commissioners have received sufficient evidence." "I

This clear statement of support for the independence of public inquiries was flatly contradicted in Judge Louis Marceau's decision at the Federal Court of Appeal. Marceau J. took the position, as I understand his ruling, that because a commission of inquiry is the creation of the government, it cannot "prevail over the will" of the government. ${ }^{12} \mathrm{He}$ could find nothing in the Inquiries $A c t^{13}$ that could be interpreted as giving commissions of inquiry that level of independence and autonomy.

But Marceau J. also seemed to be somewhat uncomfortable with the interpretation of the Inquiries Act that appeared to allow governments the freedom to turn inquiries on and off at will because he then proceeded in his decision to make an eloquent statement on behalf of the independence of inquiries.

"No one disputes the necessity of preserving the independence of commissions of inquiry as to the manner in which they may exercise their powers, conduct their investigations, organize their deliberations and prepare their reports," he wrote. "The role they play in our democracy has become much too vital to accept that the manner in which they investigate matters and formulate the conclusions and recommendations they arrive at, can be freely tampered with or influenced by anyone within or outside the government of the day, and that applies to any commission, whether or not its investigations relate to the conduct of government officials."14

Ibid. at para. 75.

lbid. at para. 76.

Ibid.

Dixon (C.A.), supra note 2 at para. 12.

R.S.C. 1985 , c. I-11.

Dixon (C.A.), supra note 2 at para. 13. 
But all this, in his view, "does not alter, in any way, the basic truth that commissions of inquiry owe their existence to the Executive" and must operate "within the parameters established by the Governor in Council."' 15

At least in this layman's opinion, Marceau J. seems to be trying to have his cake and eat it too. He states that governments shouldn't interfere with public inquiries while, in the same breath, he provides them with the legal justification for doing so. I understand that Marceau J. has to interpret the law as he understands it, but it seems contradictory to strike down the independence of public inquiries under the law while maintaining in principle the need for their independence. Perhaps it would have been better to make a straightforward ruling that rejected the notion of independence and let the chips fall where they may. The issue at stake would have been clearer.

Having decided against the notion of independence, Marceau J. had boxed himself into a corner on the question of terms of reference of public inquiries. To follow his line of reasoning to its logical conclusion, he was forced to decide that terms of reference provided to commissions of inquiry by the government do nothing more than "suggest the framework of its report."16 In other words, commissioners would appear to be free, in Marceau J.'s view, to pick and choose among their terms of reference.

I'm not competent to provide a legal argument opposing this view, but my experience tells me that it has no basis in reality. Terms of reference for public inquiries are written with extreme care and precision because everyone realizes that they represent, not a "framework," but a mandate that is as exact as possible. Inquiries that stray beyond their terms of reference can be challenged by affected parties. Inquiries that fail to cover all their terms of reference have a great deal of explaining to do. In my own experience, terms of reference are examined minutely by inquiries in the early stages of their work and form, in fact, the initial table of contents for the final report. During the course of an inquiry, there is constant citing of the terms of reference by all parties as efforts are made to expand or contract the inquiry's field of investigation.

As Simpson J. had stated in her ruling, if the government had wished to provide the Somalia inquiry with a shopping list (my term, not hers) of concerns, it could have written the terms of reference to reflect this. It could have said, for instance, "Here are ten issues - please investigate as many as you can and report in six months." (Her example, not mine.) She was satisfied that the government meant what it said in our case, that "the Governor in Council wanted an inquiry and a report on all of the Six Topics and all of the Designated Issues" specifically mentioned in our terms of reference. ${ }^{17}$

And of course this is what the public understood in our case and always understands when inquiries are appointed. When governments are faced with the kind of controversy that cries out for independent investigation, it would be politically impossible for them

17 Dixon (T.D.), supra note 1 at para. 69. 
to indicate that the terms of reference for a proposed inquiry are nothing more than a "framework" and therefore almost meaningless. As in our own case, the government usually goes to great lengths to make the terms of reference reflect questions that have already been raised publicly and to prove the government's desire to have all aspects of the controversy examined fully and impartially.

Marceau J.'s decision is helpful only in a negative sense. By demolishing the independence of public inquiries under the law and categorizing their terms of reference as nothing more than tentative proposals for research, Marceau J. has opened the way for unrestricted government interference with public inquiries and made it almost impossible for future commissioners to undertake their work, or even consider an invitation to serve, with any confidence that the invitation is genuine and that they will be allowed to do the kind of full and fair investigation that the public expects.

Under the rules set out by Marceau J., governments would appear to be free to terminate public inquiries whenever they threaten to embarrass the government. If this is true, we might as well forget about public inquiries entirely because they will soon lose credibility with the public and become useless to governments as a means of dealing with situations that defy ordinary political solutions.

But no one has suggested an alternative. Governments have always needed public inquiries of some sort and will continue to need them. These inquiries are only useful in a democracy if they are independent and seen to be independent. Somehow our system of laws and accepted political practice has to support the independence of public inquiries. This was generally the case until recent developments in the Somalia inquiry, as well as the Krever inquiry into our national blood supply which raised many of the same questions.

Marceau J.'s decision reveals the kind of chaos that remains in the wake of the government's decision to abort the Somalia inquiry. For the sake of short-term political convenience, and to pacify our military high command, the Chrétien government seriously damaged not only our own inquiry, but the institution of public inquiries and it will take a long time to restore confidence in it. 